\title{
Rancang Bangun Multi Frekuensi Rectenna Untuk Energy Harvesting Gelombang Elektromagnetik
}

\author{
Sukriyah Buwarda \\ Program Studi Teknik Elektro \\ Universitas Fajar \\ Makassar, Indonesia \\ sukriyah.warda@gmail.com
}

\author{
Asmawaty Azis \\ Program Studi Teknik Elektro \\ Universitas Fajar \\ Makassar, Indonesia \\ asmarudhy@gmail.com
}

\begin{abstract}
The increasing need for electrical energy encourages the birth of methods to utilize various forms of energy available in nature called energy harvestin. One of them is from electromagnetic waves that are massif used daily by the community. In this study, a rectifier antenna (rectenna) was created using a 5-stage voltage doubler method with the aim of generating DC electrical energy from the input of electromagnetic waves that propagate freely in the air. Electromagnetic waves are captured using two types of antennas with the aim of capturing different frequencies, namely UHF TV antennas with a working frequency of $470-806 \mathrm{MHz}$ and WiFi antennas with a working frequency of 2400 MHz commonly used by the public. Because testing is conducted in open spaces, where environmental change conditions greatly affect the captured electromagnetic geombang encroachment, DC electrical power tends to change during testing. The largest DC electricity generated by WiFi antenna input is $1,420 \mathrm{~V}$ and the average voltage is $231.7 \mathrm{mV} / \mathrm{min}$ with a distance of $90 \mathrm{~cm}$ from the largest frequency source and UHF TV antenna is $648 \mathrm{mV}$ and the average voltage is $478.16 \mathrm{mV} / \mathrm{min}$ with a distance of $0 \mathrm{~cm}$ from the largest frequency source
\end{abstract}

Keywords - Rectenna, Energy Harvesting, TV Antenna, WiFi Antenna, Multiband Antenna

\section{PENDAHULUAN}

Konsumsi energi khususnya energi listrik di masyarakat dan industri baik nasional maupun global terus mengalami peningkatan, sementara cadangan sumber daya alam berupa minyak bumi, batu bara dan gas alam yang menjadi bahan baku energi listrik semakin terbatas.

Sumber energi alternatif yang telah banyak dimanfaatkan diantaranya air yang digunakan sebagai pembangkit listrik mikrohydro, matahari dengan menggunakan solar cell digunakan pula untuk menghasilkan listrik.

Gelombang elektromagnetik pada range frekuensi radio (RF) yang selama ini hanya sebagai media untuk melakukan komunikasi antara pengirim dan penerima, dapat dimanfaatkan pula untuk memproduksi energi listrik. Sebuah alternatif yang sangat potensial mengingat pemanfaatan gelombang elektromagnetik sebagai media komunikasi saat ini sangat mudah diakses karena digunakan oleh hampir seluruh lampisan masyarakat, contohnya pada penggunaan radio, televisi, $\mathrm{Wi}-\mathrm{Fi}$, bluetooth, mobile phone, RFID dan sebagainya. Untuk memperoleh besaran energi listrik dari gelombang elektromagnetik diperlukan sebuah antena untuk menangkap gelombang elektromagnetik yang merambat bebas di alam. Gelombang elektromagnetik yang berupa arus bolak balik (AC) memerlukan sebuah penyearah (rectifier) untuk mengubah besaran gelombang elekromagnetik menjadi besaran listrik.

Integrasi antara antena yang menangkap gelombang elektromagnetik dengan rectifier yang menyearahkan arus AC menjadi arus DC disebut antena dan penyearah yang lebih umum dikenal dengan singkatan rectenna (rectifier antenna) yaitu perangkat yang dapat menangkap gelombang elektromagnetik pada range frekuensi radio (RF) yang selama ini hanya sebagai media untuk melakukan komunikasi, dapat dimanfaatkan pula untuk memproduksi energi listrik. Diantara frekuensi yang popular digunakan sehari-hari yang dapat ditangkap oleh rectenna yaitu frekuensi televisi Ultra High Frequency pada rentang frekuensi dari 470 $\mathrm{MHz}$ sampai $806 \mathrm{MHz}$ dan frekuensi Wi-Fi 2400 $\mathrm{MHz}$ yang umum digunakan oleh masyarakat.

\section{METODE PENELITIAN}

Penelitian ini bersifat eksperimental melibatkan software dan hardware. Penelitian diawali dengan membaca beberapa literatur yang berkaitan dengan judul yang diusulkan. Dari hasil studi literatur mengenai topik kajian yaitu rangkaian penyearah (rectifier), maka penelitian dilakukan dalam dua tahap yaitu simulasi dan perancangan fisik rectifier. Adapun penggambaran tahapan penelitian yang ditempuh ditunjukkan pada Gambar 1. 


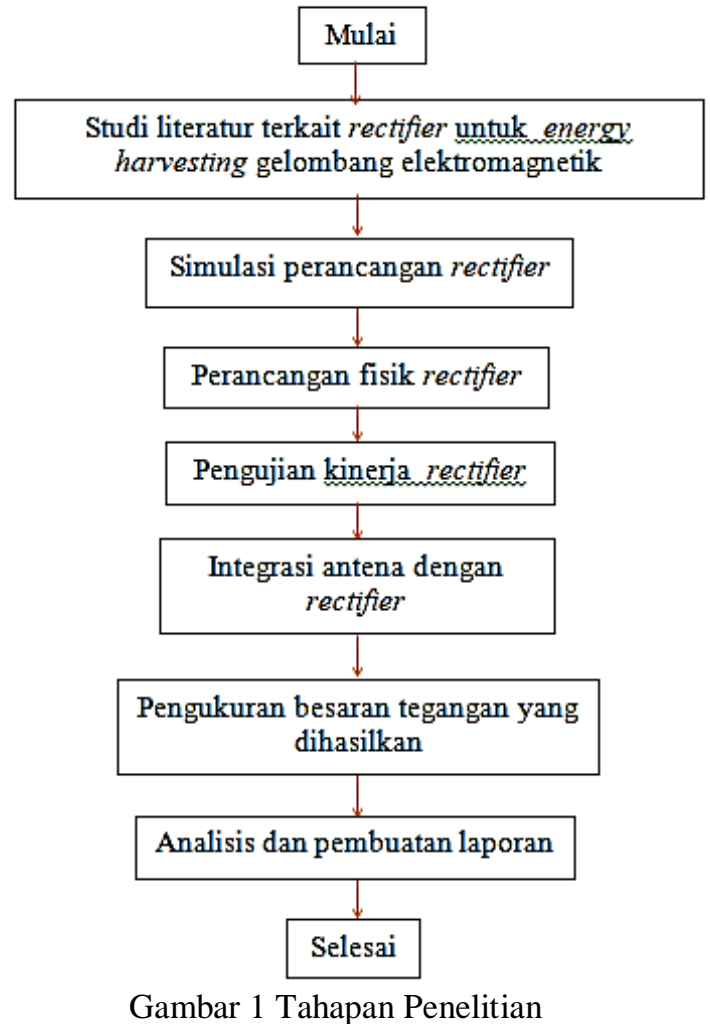

A. Tahap Simulasi

Tahapan pertama yang dilakukan adalah melakukan simulasi rangkaian menggunakan software NI Multisim 14.2 untuk mengatur letak atau posisi dari setiap komponen sehingga menghemat waktu dan proses pada tahapan pembuatan fisik rangkaian rectenna. Proses yang dilakukan pada tahapan simulasi digambarkan dalam alur proses seperti pada Gambar 2

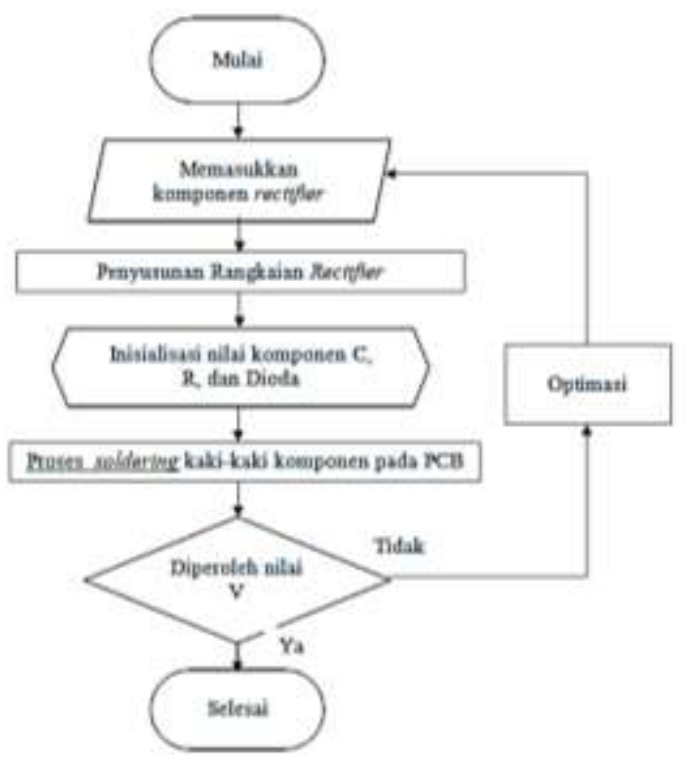

Gambar 2 Bagan Alir Rectifier Simulasi

\section{B. Tahap Pabrikasi}

Setelah proses tahapan simulasi, dilanjutkan dengan proses fabrikasi atau pembuatan fisik rangkaian rectifier yang digambarkan dalam alur proses seperti Gambar 3.

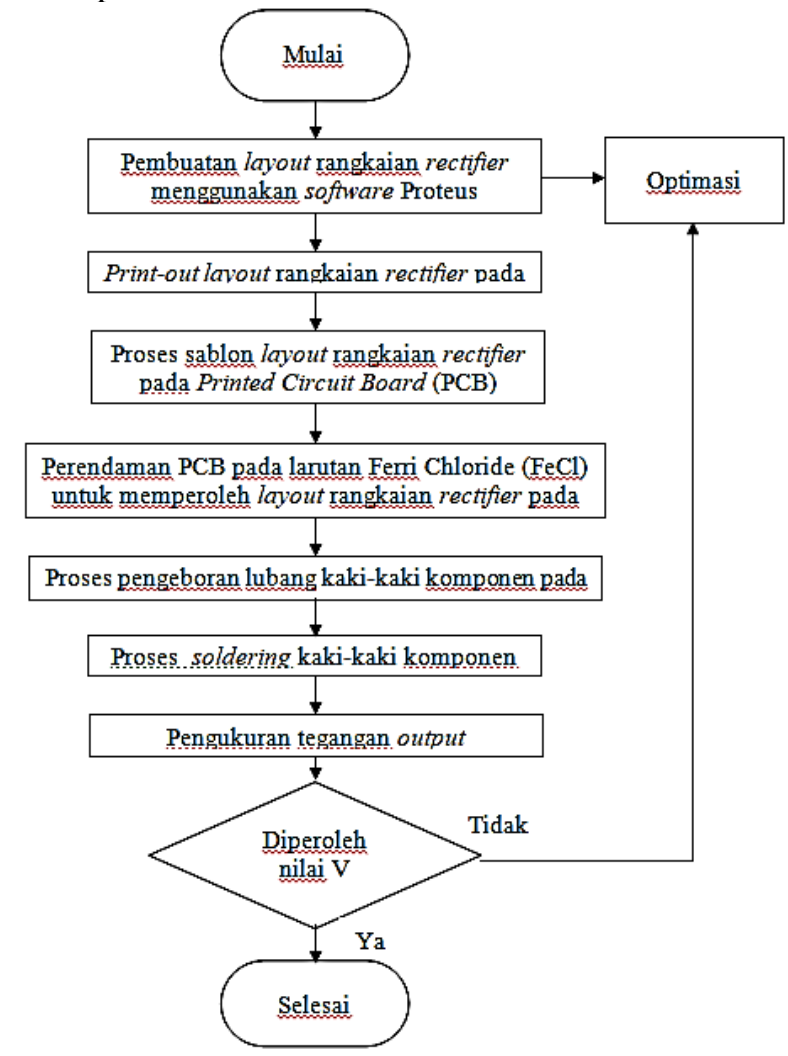

Gambar 3 Bagan Alir Pembuatan Rangkaian Rectifier

\section{HASIL DAN PEMBAHASAN}

Pengujian pertama yang dilakukan pada penelitian ini adalah menggunakan aplikasi software NI Multisim 14.2 untuk menguji tegangan output rangkaian rectifier antena dengan cara memasukkan komponen dan alat-alat seperti : kapasitor keramik 10pf, dioda BAT17-04, power AC, ground, dan multimeter lalu dihubungkan untuk sehingga menjadi sebuah rectifier antena yang dapat mengubah output sinyal AC dari antena TV UHF yang dapat menangkap frekuensi $470-806 \mathrm{MHz}$ dan antena WiFi yang dapat menangkap frekuensi $2400 \mathrm{MHz}$ dan mengubahnya menjadi tegangan DC. Seluruh simulasi ini menggunakan input power $\mathrm{AC} 0,5 \mathrm{~V}$ agar dapat membandingkan tegangan output yang dihasilkan dan tampil pada multimeter yang hasilnya di ambil setelah aplikasi dijalankan selama 1 menit, lebih jelasnya dapat dilihat pada Gambar 4.

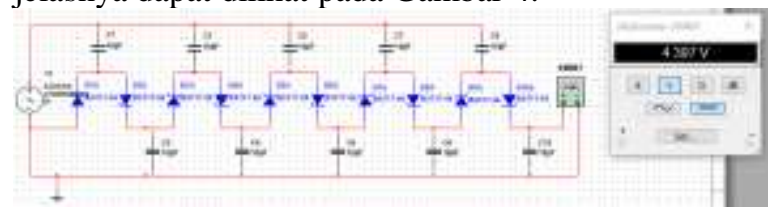

Gambar 4 Hasil Pengujian Menggunakan Input Frekuensi $470 \mathrm{MHz}$ 
Gambar 4 menunjukkan hasil susunan rangkaian pada aplikasi software NI Multisim 14.2 pada saat pengambilan data output rectifier dengan tegangan input power AC 0.5 Volt dan frekuensi TV 470MHz. Pada Gambar 4 ditunjukkan bahwa setelah rectifier dihubungkan dengan power AC yang tegangannya telah diatur, lalu dihubungkan dengan alat ukur multimeter menghasilkan output tegangan DC 4,397 Volt yang aplikasinya telah dijalankan selama 1 menit, seperti yang tampil pada layar multimeter Gambar 4

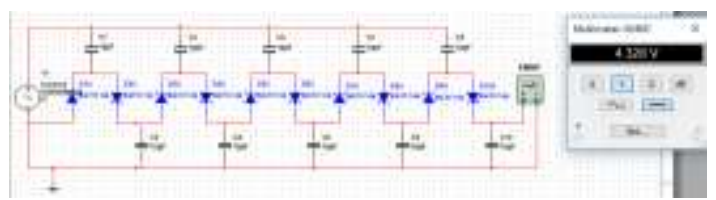

Gambar 5 Hasil Pengujian Menggunakan Input Frekuensi $638 \mathrm{MHz}$

Gambar 5 menunjukkan hasil susunan rangkaian pada aplikasi software NI Multisim 14.2 pada saat pengambilan data output rectifier dengan tegangan input power AC 0.5 Volt dan frekuensi TV 638MHz. Pada Gambar 5 ditunjukkan bahwa setelah rectifier dihubungkan dengan power AC yang tegangannya telah diatur, lalu dihubungkan dengan alat ukur multimeter menghasilkan output tegangan DC 4,328 Volt yang aplikasinya telah dijalankan selama 1 menit, seperti yang tampil pada layar multimeter Gambar 5

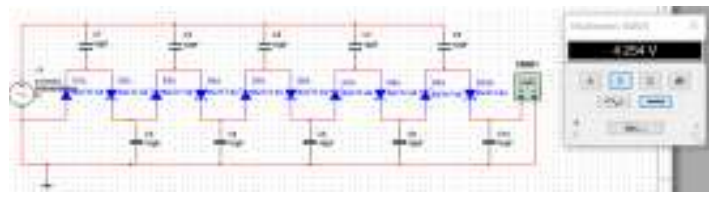

Gambar 6 Hasil Pengujian Menggunakan Input Frekuensi $806 \mathrm{MHz}$

Gambar 6 menunjukkan hasil susunan rangkaian pada aplikasi software NI Multisim 14.2 pada saat pengambilan data output rectifier dengan tegangan input power AC 0.5 Volt dan frekuensi TV 806MHz. Pada Gambar 6 ditunjukkan bahwa setelah rectifier dihubungkan dengan power AC yang tegangannya telah diatur, lalu dihubungkan dengan alat ukur multimeter menghasilkan output tegangan DC 4,254 Volt yang aplikasinya telah dijalankan selama 1 menit, seperti yang tampil pada layar multimeter Gambar 6

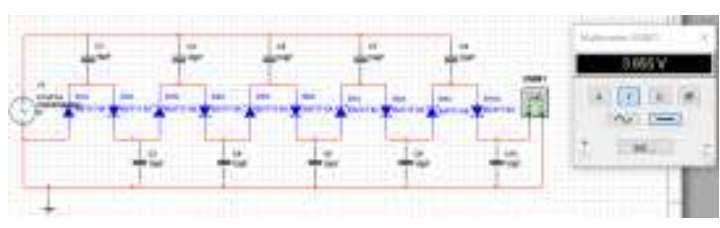

Gambar 7 Hasil Pengujian Menggunakan Input Frekuensi $2400 \mathrm{MHz}$

Gambar 7 menunjukkan hasil susunan rangkaian pada aplikasi software NI Multisim 14.2 pada saat pengambilan data output rectifier dengan tegangan input power AC 0.5 Volt dan frekuensi WiFi 2400MHz. Pada Gambar 7 ditunjukkan bahwa setelah rectifier dihubungkan dengan power AC yang tegangannya telah diatur, lalu dihubungkan dengan alat ukur multimeter menghasilkan output tegangan DC 3,955 Volt yang aplikasinya telah dijalankan selama 1 menit, seperti yang tampil pada layar multimeter Gambar 7.

Berikut adalah data tabel hasil dari pengujian rectifier menggunakan aplikasi software NI Multisim 14.2

Tabel 1 Pengujian Rectifier Menggunakan Aplikasi Software NI Multisim 14.2

\begin{tabular}{cccc}
\hline No & $\begin{array}{c}\text { Power } \\
\text { AC } \\
\text { (V) }\end{array}$ & $\begin{array}{c}\text { Frekuensi Yang } \\
\text { Digunakan } \\
\text { (MHz) }\end{array}$ & $\begin{array}{c}\text { Tegangan } \\
\text { Output Rectifier } \\
\text { Selama 1 Menit } \\
\text { (V) }\end{array}$ \\
\hline & & & \\
1. & & 470 & 4,397 \\
2. & 0,5 & 638 & 4,328 \\
3. & & 806 & 4,254 \\
4. & & 2400 & 3,955 \\
\hline
\end{tabular}

Pengukuran ini dilakukan untuk menguji tegangan keluaran yang dihasilkan rectifier antena dengan menggunakan input antena TV yang bekerja pada range frekuensi $470-806 \mathrm{MHz}$ lebih rendah dibandingkan frekuensi WiFi.

Data dokumentasi penelitian ini di ambil di kampus Universitas Fajar Makassar, depan antara gedung rektorat dan gedung baru Universitas Fajar. Sebagai bukti hasil penelitian dan berdasarkan jarak titik yang memancarkan frekuensi TV paling besar yang dijelaskan sebagai berikut :

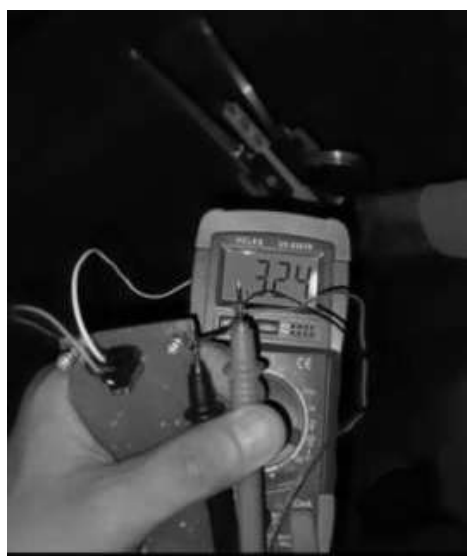

Gambar 8 Hasil Pengukuran Menggunakan Antena TV Dengan Jarak Dari Sumber Frekuensi Terbesar $0 \mathrm{~cm}$ 
Gambar 8 menunjukkan bahwa, setelah rectifier yang telah dihubungkan dengan antena TV lalu dihubungkan dengan alat ukur multimeter digital yang di atur pada skala pengukuran tegangan DC maksimal $2 \mathrm{~V}$ dan antena di arahkan ke sumber frekuensi terbesar dengan jarak $0 \mathrm{~cm}$ menghasilkan output tegangan DC $324 \times 2=$ $648 \mathrm{mV}$ dan rata-rata tegangan DC yang dihasilkan 239,08x2=478,16mV/menit

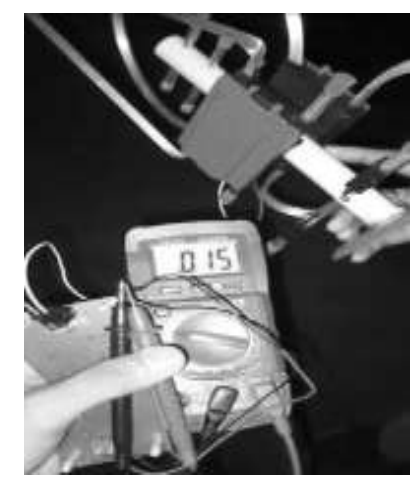

Gambar 9 Hasil Pengukuran Menggunakan Antena TV Dengan Jarak Dari Sumber Frekuensi Terbesar $330 \mathrm{~cm}$

Gambar 9 menunjukkan bahwa, setelah rectifier yang telah dihubungkan dengan antena TV lalu dihubungkan dengan alat ukur multimeter digital yang di atur pada skala pengukuran tegangan DC maksimal $2 \mathrm{~V}$ dan antena di arahkan ke sumber frekuensi terbesar dengan jarak $330 \mathrm{~cm}$ menghasilkan output tegangan DC $15 \times 2=30 \mathrm{mV}$ dan rata-rata tegangan DC yang dihasilkan $11,2 \times 2=22,4 \mathrm{mV} /$ menit

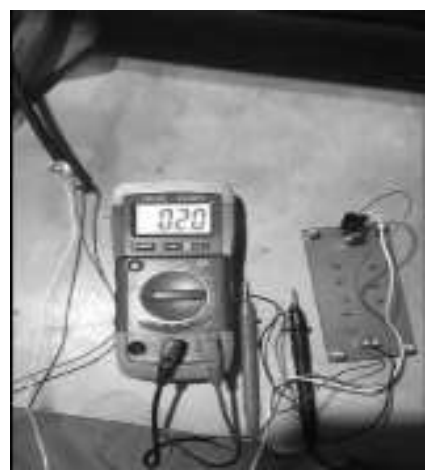

Gambar 10 Hasil Pengukuran Menggunakan Antena TV Outdoor

Gambar 10 di ambil di jalan ujung lorong 150, No. 1, Makassar, menggunakan antena TV outdoor yang digunakan sehari-hari. Pengukuran ini dilakukan untuk menguji dan membandingkan hasil pengukuran tegangan menggunakan antena indoor dan outdoor. Data hasil pengukuran antena outdoor di ukur menggunakan multimeter digital pada pengukuran skala tegangan DC maksimal $200 \mathrm{mV}$ menghasilkan output tegangan DC terbesar $2 \times 200=400 \mathrm{mV}$ dan rata-rata tegangan DC yang dihasilkan $1,25 \times 200=250 \mathrm{mV}$

Berikut adalah data tabel hasil dari pengujian rectifier menggunakan input antena TV :

Tabel 2 Pengujian Rectifier Menggunakan Inputan Antena TV Di Universitas Fajar Makssar

\begin{tabular}{|c|c|c|c|c|c|c|}
\hline No & $\begin{array}{l}\text { Lokasi } \\
\text { Pezzamba } \\
\text { an Data }\end{array}$ & $\begin{array}{l}\text { Antena Yare } \\
\text { Dizualkan }\end{array}$ & $\begin{array}{l}\text { Frekuens } \\
\text { i(MIIIx) }\end{array}$ & $\begin{array}{c}\text { Jarak Dari } \\
\text { Sumber } \\
\text { Frekuensi } \\
\text { (cas) }\end{array}$ & $\begin{array}{c}\text { Tegangan } \\
\text { Keluaran } \\
\text { Teritisas! } \\
\text { Rectifier } \\
\text { (aV) }\end{array}$ & $\begin{array}{l}\text { Rata-rata } \\
\text { Tegagaga } \\
\text { Kelasaras } \\
\text { Reenifler } \\
\text { (mWimenit) }\end{array}$ \\
\hline 1. & & & & 0 & 648 & 478,16 \\
\hline 2 & & & & 30 & 310 & 175,12 \\
\hline 3. & & & & 60 & 187 & 1039 \\
\hline 4. & & & & 90 & 64 & 45,02 \\
\hline 5. & Kampui & & & 120 & 44 & 32,6 \\
\hline 6. & Universitas & Aadoes & 470.506 & 150 & 40 & 27 \\
\hline 7. & Fajaz & 2latoor & $\mathrm{MHz}$ & 180 & 34 & 23,92 \\
\hline 8. & Makassar & & & 210 & 80 & 59,42 \\
\hline 9 & & & & 240 & 90 & 54,10 \\
\hline 10. & & & & 270 & 42 & $25, n$ \\
\hline 11. & & & & 300 & 34 & 28.4 \\
\hline 12. & & & & 330 & 30 & 224 \\
\hline 13. & $\begin{array}{c}\text { 11. Ujung } \\
\text { If. } 150 \mathrm{Na} \text {. } \\
1\end{array}$ & Outdoor & $\begin{array}{c}470.806 \\
\text { MHiz }\end{array}$ & . & 400 & 250 \\
\hline
\end{tabular}

Pengukuran ini dilakukan untuk menguji tegangan keluaran yang dihasilkan rectifier antena dengan menggunakan input dari antena $\mathrm{WiFi}$ memiliki frekuensi $2400 \mathrm{MHz}$ yang lebih tinggi dibandingkan frekuensi TV.

Data dokumentasi penelitian ini di ambil di kampus Universitas Fajar Makassar, depan gedung rektorat Universitas Fajar. Sebagai bukti hasil penelitian dan berdasarkan jarak titik yang memancarkan frekuensi WiFi paling besar yang dijelaskan sebagai berikut :

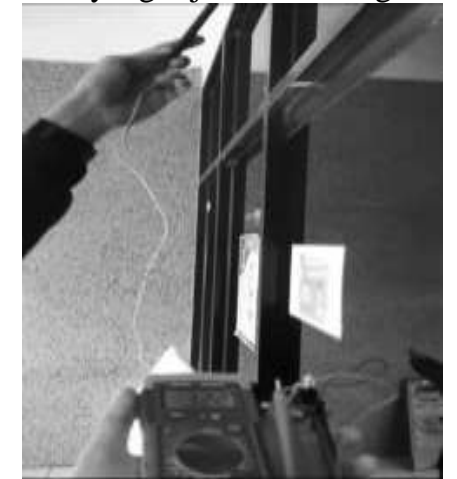

Gambar 11 Hasil Pengukuran Menggunakan Antena WiFi Dengan Jarak Dari Sumber Frekuensi Terbesar $0 \mathrm{~cm}$

Gambar 11 menunjukkan bahwa, setelah rectifier yang telah dihubungkan dengan antena WiFi lalu dihubungkan dengan alat ukur multimeter digital yang di atur pada skala pengukuran tegangan DC maksimal $2 \mathrm{~V}$ dan antena di arahkan ke sumber frekuensi terbesar dengan jarak $0 \mathrm{~cm}$ menghasilkan output tegangan DC $322 \times 2=644 \mathrm{mV}$ dan rata-rata tegangan DC yang dihasilkan 135,01x2=170,02 $\mathrm{mV} /$ menit 


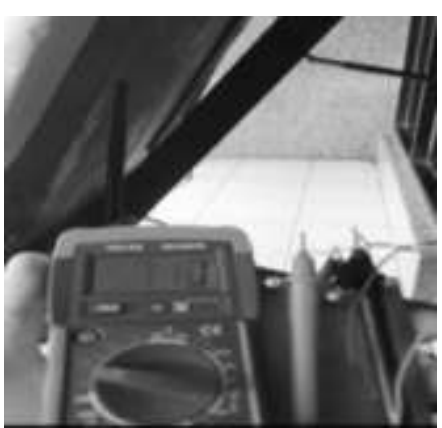

Gambar 12 Hasil Pengukuran Menggunakan Antena WiFi Dengan Jarak Dari Sumber Frekuensi $90 \mathrm{~cm}$

Gambar 12 menunjukkan bahwa, setelah rectifier yang telah dihubungkan dengan antena WiFi lalu dihubungkan dengan alat ukur multimeter digital yang di atur pada skala pengukuran tegangan DC maksimal $2 \mathrm{~V}$ dan antena di arahkan ke sumber frekuensi terbesar dengan jarak $90 \mathrm{~cm}$ menghasilkan output tegangan DC $710 \times 2=1,420 \mathrm{~V}$ dan rata-rata tegangan DC yang dihasilkan 115,5x85= $231,7 \mathrm{mV} /$ menit

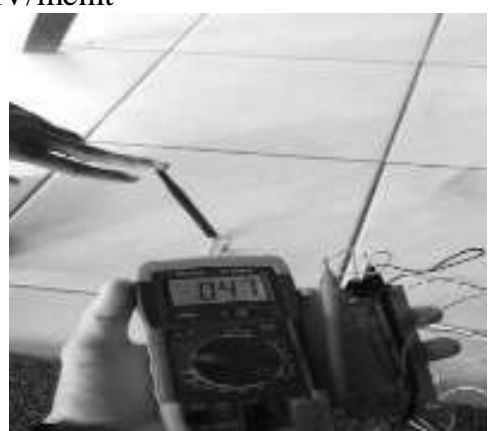

Gambar 13 Hasil Pengukuran Menggunakan Antena WiFi Dengan Jarak Dari Sumber Frekuensi $150 \mathrm{~cm}$

Gambar 13 menunjukkan bahwa, setelah rectifier yang telah dihubungkan dengan antena WiFi lalu dihubungkan dengan alat ukur multimeter digital yang di atur pada skala pengukuran tegangan DC maksimal $2 \mathrm{~V}$ dan antena di arahkan ke sumber frekuensi terbesar dengan jarak $150 \mathrm{~cm}$ menghasilkan output tegangan DC $47 \times 2=94 \mathrm{mV}$ dan rata-rata tegangan DC yang dihasilkan $18,93 \times 2=37,86 \mathrm{mV} /$ menit

Tabel 3 Pengujian Rectifier Menggunakan Inputan Antena WiFi Di Universitas Fajar Makassar

\begin{tabular}{|c|c|c|c|c|c|}
\hline $\mathbf{n}$ & $\begin{array}{c}\text { Labas } \\
\text { Prossintalen Dats }\end{array}$ & $\begin{array}{l}\text { Frekeres } \\
\text { Optes) }\end{array}$ & 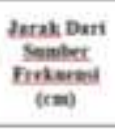 & 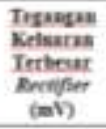 & 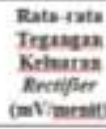 \\
\hline 1. & & & $\theta$ & 644 & 170,02 \\
\hline 2. & & & 30 & 584 & $117 \pi$ \\
\hline 3. & S.mgathithmte & $6 \mathbf{r}+2$ & 60 & $\mathbf{4 4}$ & 12656 \\
\hline 4 & Eunt Sthimene & $2000 \mathrm{sare}$ & 90 & 1.40 & $21, \pi$ \\
\hline 3. & & & 280 & 500 & 127,56 \\
\hline 5 & & & 190 & 94 & 3736 \\
\hline
\end{tabular}

\section{KESIMPULAN}

Berdasarkan hasil penelitian yang telah dilakukan, dapat disimpulkan bahwa rectifier antenna yang dapat menangkap frekuensi TV UHF 470-806 MHz dan $\mathrm{WiFi} 2400 \mathrm{MHz}$ menggunakan metode voltage doubler 5 stage dan menghasilkan energi listrik DC terbesar yaitu $1,420 \mathrm{~V}$ dengan rata-rata tegangan yang dihasilkan 231,7mV/menit menggunakan inputan antena $\mathrm{WiFi}$ frekuensi $2400 \mathrm{MHz}$ dengan jarak $90 \mathrm{~cm}$ dari sumber frekuensi terbesar. Energi listrik DC yang dihasilkan berdasarkan besar frekuensi $\mathrm{WiFi}$ yang diterima dan ketika antena WiFi di tempatkan pada posisi $90 \mathrm{~cm}$ dari sumber frekuensi terbesar menghasilkan energi listrik DC terbesar bisa disebabkan oleh antena yang menangkap sesaat frekuensi WiFi yang lebih besar karena memiliki rata-rata tegangan/menit jauh lebih kecil dibandingkan jarak terdekat.

Tegangan DC terbesar yang dihasilkan menggunakan antena TV yaitu $648 \mathrm{mV}$ dan rata-rata tegangan yang dihasilkan 478,16mV/menit dengan jarak $0 \mathrm{~cm}$ dari sumber frekuensi terbesar. Energi listrik DC yang dihasilkan berdasarkan frekuensi TV yang diterima dan menghasilkan rata-rata tegangan/menit yang tidak jauh berbeda dibanding tegangan terbesar yang dihasilkan

\section{DAFTAR PUSTAKA}

[1] Ardanta PE, Fahmi A, Wahyu Y, Elektro FT, Telkom U. Perancangan Dan Realisasi Rectenna Mikrostrip Fractal Susunan Linier Pada Frekuensi Dual Band Untuk Aplikasi Energy Harvesting. e-Proceeding Eng. 2016;3(1):415-424

[2] Balanis CA. Antenna Theory - Analysis and Design. Third Edit. Canada: John Wiley; 2012.

[3] Chandravanshi S, Member S, Sarma S Sen, Akhtar MJ. Design of Triple Band Differential Rectenna for RF Energy Harvesting. IEEE Trans Antennas Propag. 2018;(c). doi:10.1109/TAP.2018.2819699.

[4] Hamka Ikhlasul Amal NZ1, Arfianto Fahmi2 YW. Perancangan Dan Realisasi Sistem Rf Energy Harvesting Pada Frekuensi Uhf. ISSN 2355-9365 e-Proceeding Eng Vol3, No1 April 2016 | Page 568. 2016;3(1):568-575

[5] Hidayat R, Elektro JT, Tinggi S, Mandala T. Sumber Daya Wireless untuk Menghasilkan Energi Listrik Terbarukan. SINERGI. 2016;20(2):109-114

[6] James JR, Hall PS, Wood C. Microstrip Antenna Theory and Design. 12th ed. (Professors P.J.B. Clarricoats ED. S and JRW, ed.). London. United Kingdom: Peter Peregrinus; 2012.

Lisensi Creative Commons Attribution 4.0 International Licensi 